\title{
MACROZOOBENTHOS AS AN DETERMINANT OF ECOLOGICAL STATUS OF THE BOSNA RIVER
}

\section{Makrozoobentos kao determinanta ekološkog statusa rijeke Bosne}

\author{
Sadbera Troǵil -Borovac ${ }^{1}$, Rifat Ǵrijelj ${ }^{1}$, Alma Imamovil ${ }^{2}$, Samir ṇug ${ }^{1}$, Mahir Gajevil ${ }^{1}$, Adi \\ Vesni ${ }^{1}$
}

\begin{abstract}
The paper presents the distribution and diversity of macrozoobenthos composition of Bosna river up to Zenica, from 1999 to 2010. Macrozoobenthos has been chosen as an element of bioevaluation of the ecological state of running water, and according to the provisions of the Water Framework Directive. Sampling has been done by using the kick-sampling amd multihabitat method, a standard for hydrobiological research. The highest diversity of macrozoobenthos has been found in samples from the sites Rimski most (36 taxa), and the lowest was at site of the Bosna river upstream from the mouth of Ljubina river and downstream of the mouth of the Zgoǵ a river (4 taxa). According to abiotic conditions which directly affect the composition of macrozoobenthos, and using Bray-Curtis similarity, the highest degree of similarity has been found in sites which are spatially near. Taxa number and EPT taxa number were highly correlated $\left(\mathrm{R}^{2}=0,871\right)$. Saprobic index and BMWP index were calculated in assessing the ecological status of the river Bosna at the study sites. The values obtained comparing EPT taxa number and BMWP index show a high correlation $\left(\mathrm{R}^{2}=0,706\right)$. The composition and the distribution of the macrozoobenthos in the Bosna river are conditioned by abiotic parameters. Sites upstream of the mouth of the Ljubina river and downstream from the mouth of the Zgog a river represent the places with the highest pollution which is the result of point and diffuse sources of pollution.
\end{abstract}

Key words: biotic index, BMWP index, Water Framework Directive, freshwater ecosystem

\section{INTRODUCTION - Uvod}

The Bosna rivers springs out at $492 \mathrm{~m}$ a.s.l. with a large number of rheocrene springs at the southwestern part of Sarajevsko polje. It declines into a shallow valley, flowing shortly through Sarajevsko polje in the north-western direction, and then, it flows mainly up north until Doboj, where it flows in the north-eastern direction until its confluence with the Sava river near Bosanski Samac. The length of the Bosna river is $271 \mathrm{~km}$ and it is 10 to $30 \mathrm{~m}$ wide with the average depth of 2 meters. The part of the

\footnotetext{
${ }^{1}$ Faculty of Natural Sciences and Mathematics Sarajevo

${ }^{2}$ Federal Ministry of Agriculture, Water Management and Forestry
} 
river up to the town of Zenica has a terrain of rugged landslides and narrow valleys, and when exiting Sarajevo the river is surrounded with surface quarries and pits (KACANSKI ET AL. 1980). The climate of the area up to Zenica ranges from premountain until Kakanj, where, around the mouth of the Lagiva river, it passes into a typical humid continental climate. The geological base in the area of teh Bosna river is carbonate, with three types of rocks: permeable, highly permeably and poorly permeable rocks.

The waterbed of the Bosna river is under the high pressure from both point and diffuse sources of pollution. Activities ranging from building motorways, power plants etc. further undermine already disrupted state of this aquatic ecosystem. By running the Water Framework Directive (EU, 2000), a key goal is to achieve at least 'good' ecological state/potential until 2015 for every water body. Bosnia and Herzegovina is still implementing the provisions of this directive. Evaluation of the ecological status of water bodies is based primarily on biological quality elements with accompanying physical and hydromorphological elements. One such element is macrozoobenthos that can adequately give the assessment of river ecosystems' state. Organisms of the macrozoobenthos are an important part of the biology of freshwater ecosystems. Especially significant parti is the ecology of certain taxa, and the variety of reactions to changing abiotic conditions. Because of their fast reaction to the changes of physical and chemical parameters, they give the most objective view of the ecological state in aquatic ecosystems. Macrozoobenthos species composition gives reliabile information for concluding the general state of the aquatic ecosystem. They are actively included in the process of circulation of organic matter and energy flow in the aquatic ecosystems, and are consequently connected and dependent on the primary decomposers and primary producers. They are used for over 100 years for the asessment of the state of running waters (CAIRNS \& PRATT, 1993). The life span in water, taxonomic diversity and susceptibility to all kinds of stresses are all reasons for their role of the leading component in the bioassessment programme (HELLAWELL, 1977; FURSE ET AL. 2006).

The main goal of this research was to determine the ecological state of the Bosna river based on the composition and distribution of macrozoobenthos with the application of different indices and determining their suitability.

The goal includes the following tasks:

a) Determining the distribution and diversity of macrozoobenthos at the sites of the Bosna rives

b) Determining the degree of similarity/differences of ecological conditions of different sites of the Bosna river using the Bray-Curtis similarity index

c) Determining the degree of correlation between the values of the saprobic index and BMWP index in the assessment of the ecological status of the 
Bosna river, based on the macrozoobenthos composition in the samples taken from 7 sites.

\section{MATERIALS AND METHODS - Materijal i metode}

The sampling was conducted in the period between 1999 and 2010. The research sites range from Rimski Most to downstream of the mouth of the Lagiva river which covers $80 \mathrm{~km}$ of area of the river (Table 1 ).

Table 1. The research sites on the Bosna river

Tabela 1. Lokaliteti istraživanja na rijeci Bosni

\begin{tabular}{ll|l}
\hline \multicolumn{1}{l|}{ Site } & $\begin{array}{l}\text { Meters } \\
\text { ASL }\end{array}$ \\
\hline L1 & Rimski most & 494 \\
\hline L2 & Upstream from the mouth of the Miljacka river & 492 \\
\hline L3 & Upstream from the mouth of the Ljubina river & 490 \\
\hline L4 & Downstream from the city of Visoko & 420 \\
\hline L5 & Downstream from the mouth of the Zgoǵ a river & 385 \\
\hline L6 & Upstream from the mouth of the Lag்a river & 350 \\
\hline L7 & Downstream from the mouth of the Lag்a river & 345 \\
\hline
\end{tabular}

Sampling was carried out by using the kick-sampling methodology and the samples (360) are fixated in 4\% formalin in the field and further inspection was carried out in the laboratory of the Faculty of Science, Sarajevo. Insect larvae and other collected macroinvertebrates were identified to genus or species level with the aid of pertinent literature ( REYNOLDSON, 1978; KOSEL, 1989a; 1989b; STUDEMANN AT ALL., 1992; HYNES, 1977; ILLIES, 1955; FREUDE ET ALL. 1971; WARINGGER \& GRAF, 1997; BRUND NN, 1983).

Data on qualitative and quantitative composition were used for the assessment of the saprobic index by Pantle-Buck, 1955 and BMWP index (KAZANCI ET AL. 2013). The values obtained were used to analyze the correlation between the two applied indexes.

Hierarchical clustering of the zoobenthos communities was done using BrayCurtis similarity distance (BRAY \& CURTIS, 1957). Within which is a group average linkage method used for forming clusters or groups of most similar samples. The ecological statistical package PRIMER 5 was used. 
Correlation analysis suggests that one factor changes similarly to another. The analysis of the parameters was carried out according to the general model of simple linear regression:

$$
=+
$$

Statistical analysis was done using MS Excel (PAPIC, 2012).

\section{RESULTS - Rezultati}

Based on the analysis of qualitative and quantitative macroozobenthos composition of the Bosna river from Rimski Most to downstream of the mouth of the Lagiva river, the greatest diversity of 36 taxa was found in the samples from the site of Rimski most (Graph 1). The lowest diversity was found in the samples from the site upstream from the mouth of the Ljubina river (12 taxa). Higher number of taxa is registered in the samples from the site upstream from the mouth of the Lagiva river (26 taxa) and downstream from the mouth of the Lagia river (25 taxa).

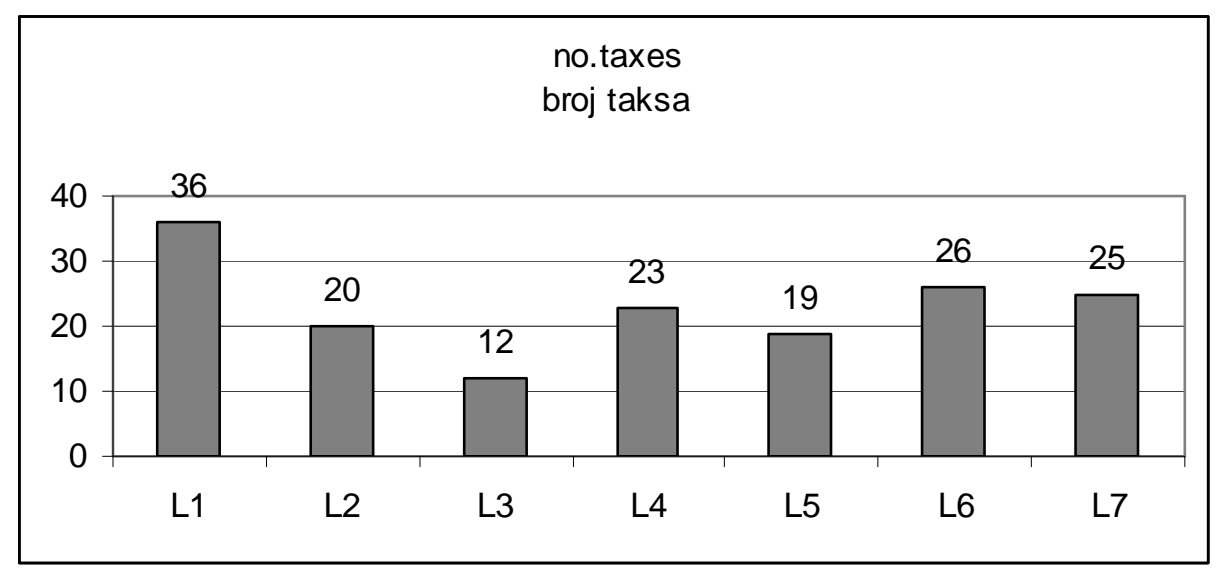

Figure 1. The number of taxa in the composition of macrozoobenthos of the Bosna river from Rimski Most to downstream of the mouth of the Lagiva river Grafikon 1. Broj taksa u sastavu makrozoobentosa rijeke Bosne od Rimskog mosta do nizvodno od ušća Lašve

A high correlation $\left(\mathrm{R}^{2}=0,871\right)$ between the total number of taxa in the composition of macrozoobenthos (Graph 2) and the number of EPT taxa (Ephemeroptera, Plecoptera and Trichoptera). With increasing the total number of taxa, the increase in number of taxa of EPT groups was noted. The site Rimski Most stands out with the highest number of taxa $i$ 36. furthermore, 50\% of them are the species from the 3 groups (EPT groups). The lowest number was noted in the samples from the site upstream from Ljubina (4) and dowsntream from Zgoǵca (4). 


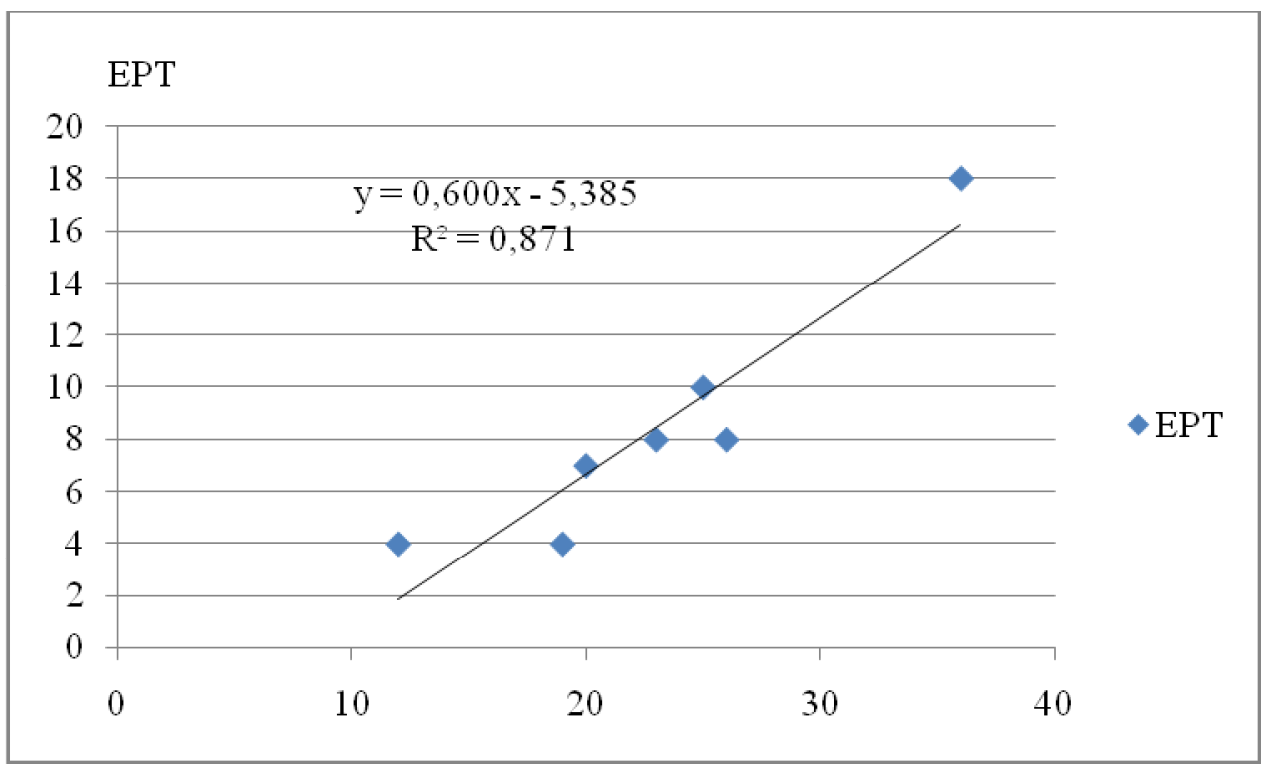

Figure 2. Total taxa number (UBT) correlation in the macrozoobenthos composition of the sites on the Bosna river and EPT taxa

Grafikon 2. Prikaz korelacije ukupnog broja taksa (UBT) u sastavu makrozoobentosa lokaliteta na rijeci Bosni i EPT taksa

\section{Similarity/dissimilarity index Bray-Curtis, 1957}

According to the degree of similarity, 3 groups stand out (Fig. 1) and the sites upstream from the mouth of the Miljacka river, upstream from the mouth of the Ljubina river and downstream from the mouth of the Zgog a river make one group. The highest degree of similarity is within the composition of macrozoobenthos of the following sites: upstream from the mouth of the Lagiva river, downstream from the mouth of the Lagiva river and downstream from the mouth of the Zgoǵ a river. They represent the second group of sites. The site Rimski Most shows the highest degree of dissimilarity compared to all other sites and represents the third group. All sites within one group are teritorrialy close which affected the obtained results. 


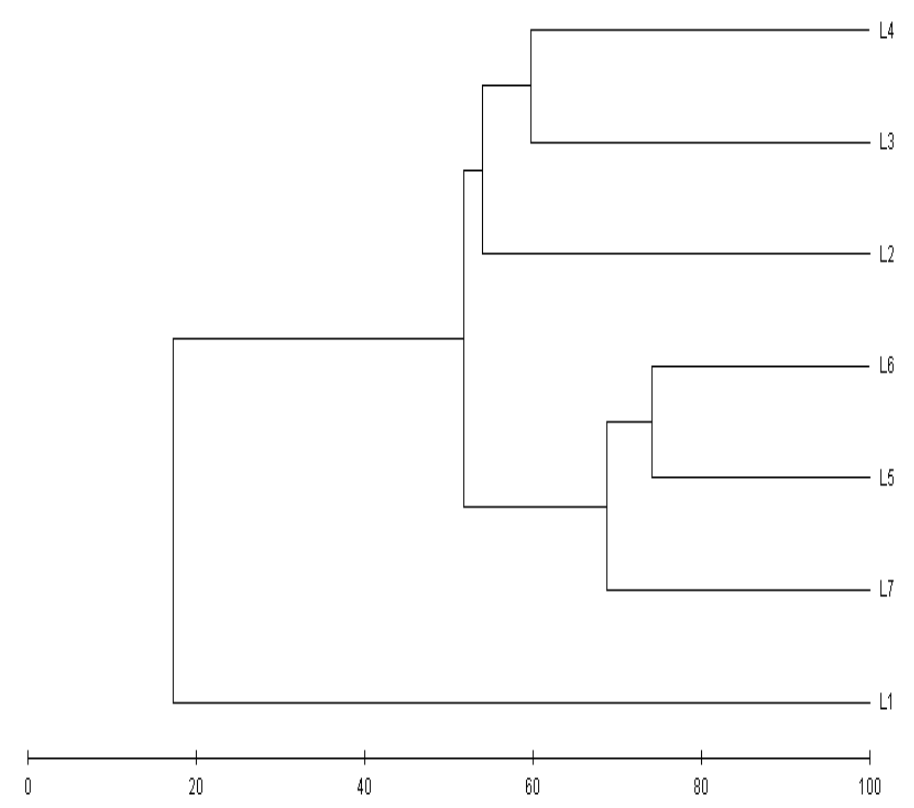

Figure 3. The values of Bray-Curtis index (group average linkage) for the macrozoobenthos composition in the samples from the sites of the Bosna river during the period between 1999 and 2010

Slika 3. Vrijednosti Bray-Curtis-ovog indeksa (povezivanje po prosjeku grupa) za sasatav makrozoobentosa u uzorcima na lokalitetima rijeke Bosne tokom 1999-2010. godine

\section{Saprobic index and BMWP index}

The application of the saprobic index for the assessment of water quality of the Bosna river at the sites researched has determined that the valuevariates from 1.68 at Rimski Most up to 2.85 at the site upstream from the mouth of the Ljubina river (table 2). The only site that stands out for its ecologically good state is the site at Rimski Most, while the impact of waste water pollution and other sources was registered at other sites. The values of BMWP index varied from 129 at Rimski Most which points to a preserved habitate, up to 41 at the site upstream from the mouth of the Ljubina river which indicates the intensified impact and place of the greatest pollution. Both indices point to sites with increased stress for aquatic ecosystem of the Bosna river. 
Table 2. Values of the saprobic and BMWP indices for the composition of macrozoobenthos at the researched sites of the Bosna river

Tabela 2. Vrijednosti saprobnog i BMWP indeksa za sastav makrozoobentosa na istraživanim lokalitetima rijeke Bosne

\begin{tabular}{|l|c|c|c|c|}
\hline \multirow{2}{*}{ Localities } & \multicolumn{2}{l|}{ BMWP index } & \multicolumn{2}{l|}{ Saprobic index - SI } \\
\cline { 2 - 5 } & value & category & value & category \\
\hline Bosna-Rimski most & 129 & I & 1,68 & I-II \\
\hline Upstream from the mouth of the Miljacka river & 96 & II & 2,17 & II \\
\hline Upstream from the mouth of the Ljubina river & 41 & III & 2,85 & III \\
\hline Downstream from the city of Visoko & 93 & II & 2,26 & II \\
\hline Downstream from the mouth of the Zgoǵ a river & 49 & III & 2,39 & II-III \\
\hline Upstream from the mouth of the Laǵva river & 92 & II & 2,23 & II \\
\hline Downstream from the mouth of the Lağva river & 114 & I & 2,30 & II \\
\hline
\end{tabular}

The representation and distribution of the families of the macrozoobenthos with a tolerable value (Armitage et AL.1983, HelLaWel, 1986) can be seen in table 3, as well as a great diversity of snails present in large abundances of populations in the samples of benthos at the site upstream from the mouth of the Lagia river. The high density of oligocheta and insects of the familiy Chironomidae was found in most sites, while the greatest number of oligocheta is noted upstream from the mouth of the Miljacka river (2270 individuals). A greater number, as well as the diversity of leeches (Hirudinea) has been noted and they are present in the samples from all sites. 14 families from the EPT groups (Ephemeroptera, Plecoptera i Trichoptera) have been noted and they are mostly present in the samples from the site Rimski Most (Baetidae, Heptagenidae, Ephemerellidae, Siphlonuridae, Perlodidae, Leuctridae, Limnephilidae, Odontoceridae, Leptoceridae i Sericostomatidae). 
Table 3. the distribution of the families of macrozoobenthos by the sites of the Bosna river and tolerable values for taxa

Tabela 3. Distribucija familija makrozoobentosa po lokalitetima rijeke Bosne i tolerantne vrijednosti za takse

\begin{tabular}{|c|c|c|c|c|c|c|c|c|}
\hline 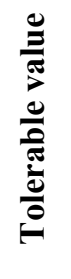 & 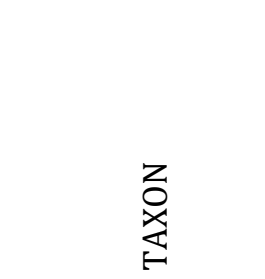 & 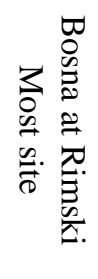 & 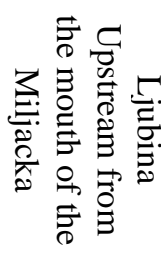 & 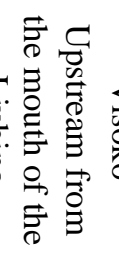 & 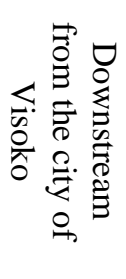 & 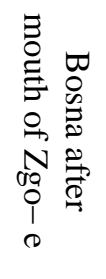 & 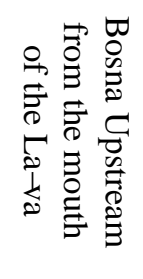 & 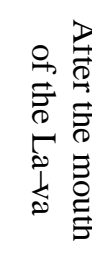 \\
\hline 5 & Planaridae & + & & & & & & \\
\hline 5 & Dugesiidae & & & & + & + & & \\
\hline 6 & Ancylidae & + & + & & + & & & + \\
\hline 3 & Melanopsidae & & & & + & + & + & + \\
\hline 3 & Bythinidae & + & & & & & & \\
\hline 3 & Planorbidae & & & & & & + & \\
\hline 3 & Lymnaeidae & + & & & & & & \\
\hline 6 & Neritidae & & & & & + & + & + \\
\hline 3 & Valvatidae & + & & & & & & \\
\hline 6 & Viviparidae & & + & + & & & & \\
\hline 3 & Sphaeridae & & + & & & & + & + \\
\hline 6 & Unionidae & & + & & & & & \\
\hline 1 & $\begin{array}{l}\text { OLIGOCAHET } \\
\text { A }\end{array}$ & + & + & + & + & + & + & + \\
\hline 3 & Erpobdellidae & + & + & + & + & + & + & + \\
\hline 3 & Glossiphoniidae & & + & + & + & + & + & + \\
\hline 6 & Gammaridae & + & + & & & & & + \\
\hline 3 & Asellidae & + & + & & + & & & \\
\hline 4 & Baetidae & + & & + & + & + & + & + \\
\hline 4 & Caenidae & & & & + & & + & \\
\hline 10 & Leptophlebidae & & & & + & & & \\
\hline 7 & Ephemerellidae & + & + & & + & & + & + \\
\hline 8 & Heptagenidae & + & + & & & & & + \\
\hline 10 & Siphlonuridae & + & + & & & & & \\
\hline 9 & Perlodidae & + & + & & + & & + & + \\
\hline 9 & Leuctridae & + & & & + & & & \\
\hline 7 & Limnephilidae & + & + & + & & & & + \\
\hline 10 & Goeridae & & & & & & & + \\
\hline
\end{tabular}


Macrozoobenthos as an determinant of ecological status of the Bosna river

$\begin{array}{lllllllll}5 & \text { Hydropsychidae } & & + & + & + & + & + & + \\ 10 & \text { Leptoceridae } & & & & & & + & \\ 10 & \text { Odontoceridae } & + & & & & & & \\ 10 & \text { Sericostomatidae } & + & & & & & & + \\ 5 & \text { Dytiscidae } & + & & & & & & \\ 5 & \text { Eminthidae; } & + & + & & & & & \\ 2 & \text { Chironomidae } & + & + & + & + & + & + & + \\ 5 & \text { Limoniidae } & + & & + & + & + & + & + \\ 5 & \text { Simulidae } & & & + & + & & + & + \\ 4 & \text { Tabanidae } & & & & + & & + & \\ 5 & \text { Tipulidae } & + & & & + & & & + \\ 6 & \text { Gomphidae } & & + & & & + & + & + \\ 6 & \text { Cordulegastridae } & & & & & & + & \\ 5 & \text { Calopterygidae } & & & & & + & + & \\ \text { Total } & \text { BMWP } & \mathbf{1 2 9} & \mathbf{9 6} & \mathbf{4 1} & \mathbf{9 3} & \mathbf{4 9} & \mathbf{9 2} & \mathbf{1 1 4}\end{array}$

By calculating the correlation, a close connection $\left(\mathrm{R}^{2}=0,706\right)$ was noted between BMWP values and values of saprobic index for the macrozoobenthos composition of sites of the Bosna river (Graph. 3).

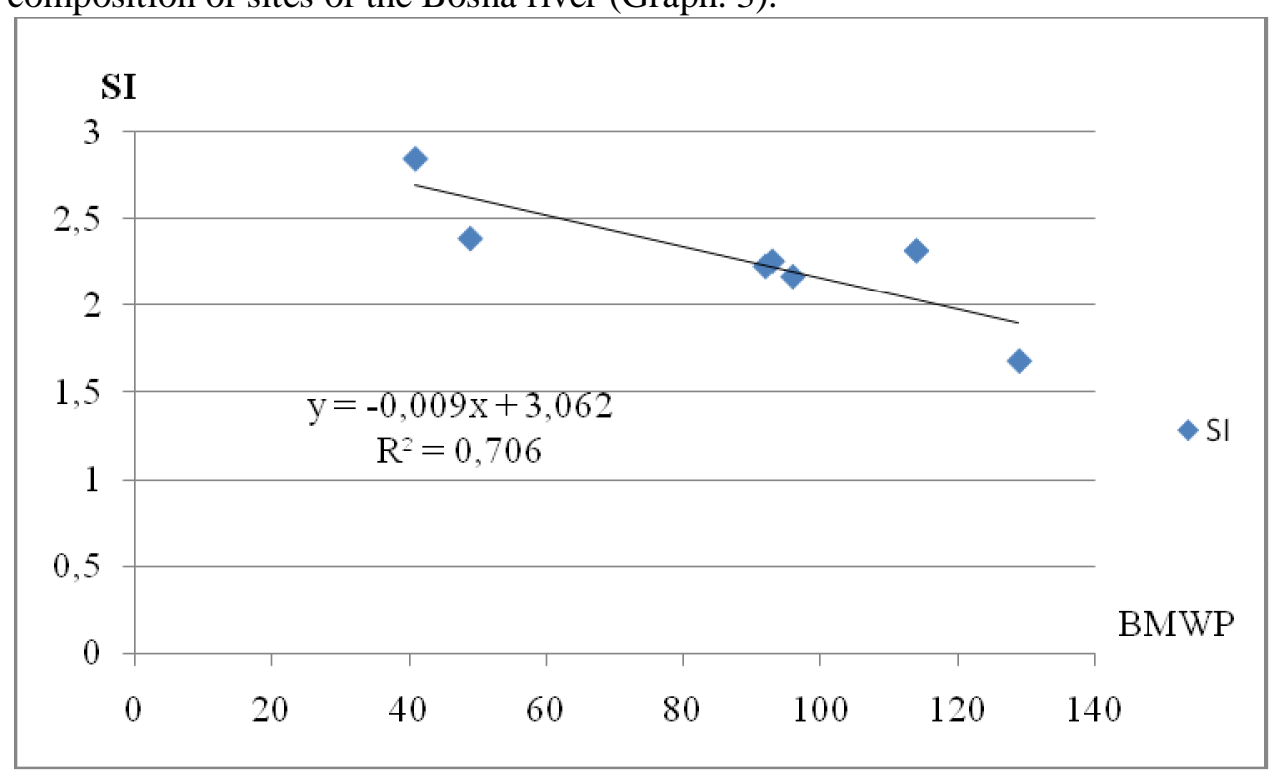

Graph 3. Correlation between the values of Saprobic index (SI) and BMWP index for the composition of macrozoobenthos of samples at sites of the Bosna river

Grafik 3. Korelacija između vrijednosti saprobnog indeksa (SI) i BMWP indeksa za sastav makrozoobentosa uzoraka na lokalitetima rijeke Bosne 


\section{DISCUSSION - Diskusija}

The use of different elements in the assessment of the status of aquatic ecosystems dates over a century, but since the year 2000 with the establisment of Water Framework Directive, the construction of unified system has begun. However, it is open for adaptations in respective countries. Basic provisions are aimed at finding ways of establishing aquatic ecosystems of good status / potential, and consequently carrying out monitoring which will give an objective view of thze status. Countries in the region are already at the end of these provisions, particularly EU countries, especially Slovenia (URBANIC, 2012).

Macrozoobenthos, with its taxonomic composition and autecology of certain species, is one of the most important biological elements of teh provision of ecological state/potential of aquatic ecosystems.

There is a lot of data about the composition and distribution of macrozoobenthos in the waters of $\mathrm{BiH}$, but there is still not enough published literature data about this component. In the composition of macrozoobenthos of the Bosna river, a great diversity of eurivalent taxa (Oligochaeta, Chironomidae, Hirudinea, Gastropoda) stand out. They dominate the macrozoobenthos composition

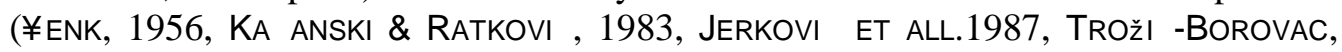
2002). According to the results presented, the sites of confluence of waste waters had higher degree of degradation. At the site of the Bosna river upstream from the Ljubina river anegativ influence of the mouth of the Miljacka river can be seen, where the lowest number of taxa of macroinvertebrates was registered in the samples, and the values of both indices point to pollution and changed ecological conditions. The second site is after the mouth of the Zgog a river which, receives all waste waters of Kakanj and that is consequently reflected in a low biodiversity, muddy sediment and water odour. Saprobic index has been used in our country for more than 50 years for the water quality assessment, but the use of biotic indices, primarily of BMWP index, was determined by the regulation by the country authorities. Comparison of values of these two indices indicated a high degree of correlation, confirming its applicability. For $\mathrm{BiH}$ it is necessary to modify the saprobic and tolerable values according to the ecological circumstances because that will largely eliminate the drawbacks of their application. The Bosna River requires far more extensive analysis due to conducting intense negative activities. The area of the Bosna river at the site Rimski Most suffers a greater antropogenic pressure, which likely reflects on overall state of this river downstream. Management of ecosystems is possible only with ecosytemic approach which will include all the elements relevant to functioning and undisturbed energy flow and organic matter circulation. 


\section{CONCLUSIONS - Zaključci}

At seven sites if the Bosna river during the period from 1999 to 2010, a great diversity in macrozoobenthos composition ahs been determined with the emphasis on the site of Rimski Most. A relatively high relation between the total number of macroinvertebrate taxa and the number of EPT group has been ndetermined, which indicates that a high diversity reflects auspicious existence. By comparing the values of the saprobic index with BMWP index, a high correlation is noted wich points to the objectivity of the apllciation of these two indices in the evaluation of the ecological status of our countries running waters. Macrozoobenthos, in combination with hydromorphological paraameters, finding the adequate index, can objectively point to the ecological state of the stream of the Bosna river.

\section{REFRENCES - Literatura}

Armḳage, P. D., Moss, D.,Wrịht, J. F., And Furse M. T. (1983). The performance of a new biological water quality score system based on macroinvertebrates over a wide range of unpolluted running-water sites, Water Research, vol. 17, no. 3, pp. 333 ï 347.

BRAY, J. R. AND J. T. CURTIS. (1957). An ordination of upland forest communities of southern Wisconsin. Ecological Monographs 27:325-349.

BRUNDKN, L. 1983. The larvae of Podonominae (Diptera: Chironomidae) of the Holarctic region - Keys and Diagnoses. Ent. Scan. Suppl. 19. 23-31.

CAIRNS, J. \& PRATT, J. R. (1993). A history of biological monitoring using benthic macroinvertebrates. In Rosenberg, D. M. \& V. H. Resh (eds), Freshwater Biomonitoring and Benthic Macroinvertebrates. Chapman and Hall, New York: 10ї 27.

Freude, H., K.W. Harde \& G.A. Lohse 1971. Die Käfer Mitteleuropas. Band 3. Goecke \& Evers, Krefeld, $157 \mathrm{pp}$.

Furse, M., D. Hering, O. Moog, P. Verdonschot, R. K. Johnson, K. Brabec, K. Gritzalis, A. Buffagni, P. Pinto, N. Friberg, J. Murray-Bligh, J. Kokes, R. Alber, P. Usseglio-Polatera, P. HaAse, R. Sweeting, B. Bis, K. Szoszkiewicz, H. Soszka, G. SPRINGE, F. SPORKA \& I. KRNO (2006). The STAR project: context,objectives and approaches. Hydrobiologia 566: 3 Ï 29.

Hellawell, J. M. (1977). Change in natural and managed ecosystems:detection, measurement and assessment. Proceedings of the Royal Society of London. Series B: Biological Sciences 197: 31 ï 35

HYNES, H.B.N. 1977. A Key to the adults and nymphs of the British Stoneflies (Plecop-tera). With notes on their Ecology and Distribution. Freshwater Biological Association. Scientific Publication No.7, 90 pp. 
ILLIES, J. 1955. Steinfliegen oder Plecoptera. In: Dahl, F. (ed.). Die Tierwelt Deutschlands und der angrenzenden Meeresteile 43, 1-150.

JeRkoví́, L., KaĹanski, D, BlagojeVIĹ, S., Hafner, D., MarinkoviĹGospodnetiĹ, M., TanasiJeVí́, M., Vagner, D., KosoriĹ, n.., KapetanoviĹ, N. (1987). Biolog̉ke karakteristike vodenih ekosistema (Sarajeva i okoline). Elaborat. Prirodnomatematil ki fakultet Sarajevo.

Kálanski, D., Abadgilí, S., Stilinovilí, S., Blagojevilí, B., Hafner, D., MARINKOVIĹ-GosPODNETIĹ, M., TANASIJEVIĹ, M., VAGNeR, D., KosoriĹ, n.., KAPETANOVIĹ, N. (1980). Bioloǵki aspekt degradacije kvaliteta vode ekosistema rijeke Bosne. Elaborat. Biologiki Institut Univerziteta u Sarajevu.

Kazanck N. , Türkmen, G., Ekingan, P., And Baḳören, Ö. (2013). Preparation of a biotic index (Yekilēmak-BMWP) for waterquality monitoring of Yekilēmak River (Turkey)by using benthic macroinvertebrates. Review of Hydrobiology 6,1: 1-29

KosEL, V. 1989a. Malostetinavce (Oligochaeta) vo vodohospodarskej praxi (Oligochaets in water management). Informacny bulletin, III. determinacny kurz makrozoobentosu, Dolni Vestonice 1989, 14-24.

KoǴEL, V. 1989b. Pijavice (Hirudinea) a ich vyuǵitie $v$ bioindikácii saprobity (Leeches (Hi-rudinea) and their application in bioindication of saprobity). In: Hodnocení bentosu tekoucích vod. MLVD L SR, Praha, 45-60. (In Slovak)

PANTLE, R., Buck, H. (1955). Die Biologishe Uberwaschung der Gewasserund die Daestellung der Ergebnisse. GWF, 96, 603 pp.

PAPIĹ, M. (2012). Primjenjena statistika u MS-Excelu, Naklada Zoro, Zagreb

ReYnoldson, T.B. 1978. A key to the British species of Freshwater Triclads (Turbellaria, Paludicola). Freshwater Biological Association. Scientific Publication No. 23, $26 \mathrm{pp}$.

Studemann, D., P. Landolt, M. Sartori, D. Hefti \& I. Tomka 1992. Ephemeroptera. In: Schweizerische Entomologische Gesellschaft (ed.). Insecta Helvetica ï Fauna. Bd. 9, 173 pp.

ǴENK, F. (1956). Faunistil ko-ekolog̉ka ispitivanja izvorskog dijela rijeke Bosne.Acta ichtyologica Bosniae and Herzegovinae, 2:29-61.

TROǴ̣L-BOROVAC, S. (2002). Istraǵivanje makroinvertebrata bentosa rijeke Bosne i pritoka u ocjeni kvaliteta vode. Doktorska disertacija. Prirodno-matematil ki fakultet Sarajevo.

URBANIL, G. 2012. Hydromorphological degradation impact on benthic invertebrates in large rivers in Slovenia. Hydrobiologya. doi:10.1007/s10750-0121430-4

WARINGGER, J. \& W. GRAF 1997. Atlas der österreichischen Köcherfliegenlarven unter Einschluß der angrenzenden Gebiete. Facultas Universitätsverlag, Wien, 286 pp. 


\section{SAŽETAK}

Rijeka Bosna je u prog̉osti bila istraǵivana sa aspekta stupnja degradacije i analize abiotskih i biotskih parametara (KAĹ ANSKI ET. AL 1980, JERKOVIĹ ET AL. 1987, TROG̣IĹBorovac, 2002). Dosadaǵnji podaci ukazivali su na prisutno i permanentno zagaĹenje prisutnih tal kastih i difuznih izvora. U vrijeme aplikacije odredbi Okvirne direktive o vodama i na podrul ju Bosne i Hercegovine, veĺ e rijeke, kao ġo je rijeka Bosna, prerdstavljaju poseban problem. Materijal za rad predstavlja sintezu dosadağjih podataka (1999-2010 god.) o kvalitativno-kvantitativnom sastavu makrozoobentosa rijeke Bosne na sedam lokaliteta (Rimski most do nizvodno od uǵ a Lag̉ve). Ukupno je analizom obuhval eno 390 uzoraka. Metodologija uzorkovanja je multi-habitat ali nije zahvatila sredinu korita uslijed velike dubine.

Primjenjeni su saprobni indeks (PANTLE \& BUCK, 1955) i BMWP indeks, a kao podloga za utvrLivanje korelacije u ocjeni ekolog̉kog stanja istraǵvanog dijela vodotoka rijeke Bosne.

$\mathrm{U}$ analizi je primjenjen Bray-Curtis indeks sli! nosti ili razli! itosti za uzorke makrozoobentosa.

Rezultati rada ukazuju na najveĺ u raznovrsnost u sastavu makrozoobentosa na lokalitetu Rimski most (36 takse), a najmanja na lokalitetu Bosne uzvodno od uǵ a Ljubine (12 taksa). Najveĺ e ul eğ e skupina Ephemeroptera, Plecoptera i Trichoptera (EPT) konstatovano je takoLe u uzorcima na lokalitetu Rimski most (18) ġo ovaj lokalitet i prema primjeni klastera Bray-Curtis izdvaja od svih ostalih lokaliteta. Po sli! nim abiotil kim uvjetima i sastavu makrozoobentosa grupisani su lokaliteti koji su prostorno bliski. Najveĺ i stupanj slil nosti pokazuju uzorci rijeke Bosne na lokalitetu poslije uǵ a Zgoǵ e, uzvodno od uǵ a Lag̉ve i nizvodno od uğ a Lag̉e).

Primjenjeni indeksi u ocjeni ekolog̉kog stanja rijeke Bosne, a na osnovu sastava makrozoobentosa, poakazuju veliku povezanost $\left(R^{2}=0,706\right)$.

Za oba indeksa se mora istaknuti, da svojim vrijednostima ukazuju na dva mjesta poja! anog zagaĹenja. Rijeka Bosna poslije uğ a Miljacke (lokalitet uzvodno od uǵa Ljubine) predstavlja mjesto najveĺ eg stresa za ovaj akvatil ni ekosistem, koji naruğiva ekolog̉ke prilike, a takav status se zadrǵava ili pogorǵava do samog uǵ a u rijeku Savu. Drugi lokalitet pojal anog zagaL'enja ali manjeg intenziteta je na lokalitetu Bosne poslije uǵa Zgoğe. Manja revitalizacija abiotskih prilika rezultat je pojalanog protoka i prog̈renja korita na lokalitetu Bosne nizvodno od Visokog. Ovakve abiotske prilike i utok pritoka sa veĺ im stupnjem kvaliteta vode (Ribnica, Lag̉va, Krivaja) rezultiraju povel anje raznovrsnosti makrozoobentosa. BMWP indeks ima veliku vrijednost za uzorke makrozoobentosa Bosne poslije uǵa Lağve, ġo je posljedica direktnog utoka rijeke Lağve i drifta organizama. Rijeka Bosna zahtijeva poseban metodologiki pristup u analizi sastava hidrobionata, na osnovu kojih ĺ e se i objektivnije mol i ukazati na najadekvatniji pristup upravljanju. 
Dobiveni rezultati ipak potvrLuju potrebu primjene viǵe indeksa u ocjeni ekolog̉kog stanja tekuĺica, ali i neophodnost uskalaLivanja dosadağjih podataka o sastavu makrozoobentosa i dopuna podataka sa podacima ! itavog presjeka korita rijeke. 